\title{
BENCHMARKING METHOD \\ FOR ESTIMATION OF BIOGAS UPGRADING SCHEMES
}

\author{
D. Blumberga, Ģ. Kuplais, I. Veidenbergs, E. Dāce \\ Riga Technical University, Institute of Environment and Energy Systems, \\ 1 Kronvalda Blvd., Riga, LV-1010, LATVIA

\begin{abstract}
The paper describes a new benchmarking method proposed for estimation of different biogas upgrading schemes. The method has been developed to compare the indicators of alternative biogas purification and upgrading solutions and their threshold values. The chosen indicators cover both economic and ecologic aspects of these solutions, e.g. the prime cost of biogas purification and storage, and the cost efficiency of greenhouse gas emission reduction. The proposed benchmarking method has been tested at "Daibe" - a landfill for solid municipal waste.
\end{abstract} indicators.

Key words: benchmark, biogas, biogas treatment, upgrading, purification,

\section{INTRODUCTION}

The development of biogas utilisation and upgrading has both horizontal and vertical dimensions. The former is characterised by the necessity to develop the renewable energy sources and the policy directed to reducing the impact of climate changes. The horizontal activities can be regulated by legislation, whereas the vertical dimension of biogas utilisation is associated with the development of specific technological solutions.

It is calculated that the potential of biogas production in Europe is so great that it suffices for replacing 12 to $20 \%$ of natural gas consumption. Because of large capital investments needed and complicated infrastructure, only $50 \%$ of currently produced biogas is used. Therefore the process of biogas substitution for natural gas is very slow [1]. Upgraded biogas is one of the cleanest fuels, with a minor impact on the environment and human health [2].

Biogas is one of the alternative energy sources, and the best possible actions after collection of biogas emitted from landfills are to raise its quality and properly utilise it. Biogas, to a various extent, can be used in all types of the equipment intended for the use of natural gas; however, for definite type equipment only upgraded biogas is required.

For utilisation of biogas as a renewable energy source the following main ways exist:

- in cogeneration (combined production of heat and power);

- its conversion into another chemical form, obtaining such substances as, e.g., methanol $\left(\mathrm{CH}_{3} \mathrm{OH}\right)$, ammonia $\left(\mathrm{NH}_{3}\right)$ (or carbamide $\left(\left(\mathrm{NH}_{2}\right)_{2} \mathrm{CO}\right)$, or clean methane carbon dioxide;

- as transport fuel;

- injection into natural gas grid. 
For the use of biogas as transport fuel or its injection into a natural gas grid the only suitable fraction in biogas is methane. Other its components (carbon dioxide, hydrogen sulphide, hydrogen, etc.) are unsuitable for these purposes, undesirable or even hazardous; therefore, they should be removed from biogas, while the methane content should be increased.

\section{UTILISATION OF BIOGAS}

Biogas as transport fuel is one of the most promising alternatives, since the energy is here obtained from biomethane (upgraded biogas). Biogas is used in transport in such countries as Sweden, Switzerland, Germany, France, and, recently, in the Czech Republic.

Requirements to biogas for its use as transport fuel [3]

\begin{tabular}{|l|c|c|}
\hline \multicolumn{1}{|c|}{ Characteristic/parameter/indicator } & Unit & Required \\
\hline Wobbe index (lower) & $\mathrm{MJ} / \mathrm{nm}^{3}$ & $44.7-46.4$ \\
Methane $\left(\mathrm{CH}_{4}\right)$ (volume at $\left.273 \mathrm{~K} ; 101.3 \mathrm{kPa}\right)$ & $\%$ & $97 \pm 1$ \\
\hline Octane number & --- & $>130$ \\
\hline Water $\left(\mathrm{H}_{2} \mathrm{O}\right)$ amount & $\mathrm{mg} / \mathrm{nm}^{3}$ & $<32$ \\
\hline $\mathrm{CO}_{2}+\mathrm{O}_{2}+\mathrm{N}_{2}$ (maximum volume) & $\mathrm{vol}-\%$ & 4,0 \\
$\mathrm{O}_{2}($ maximum volume) & $\mathrm{vol}-\%$ & $<1,0$ \\
\hline Total sulphur content & $\mathrm{mg} / \mathrm{nm}^{3}$ & $<23$ \\
\hline Total content of carbon compounds (calculated as $\left.\mathrm{NH}_{3}\right)$ & $\mathrm{mg} / \mathrm{nm}^{3}$ & $<20$ \\
\hline
\end{tabular}

For the use of biogas as transport fuel the quality of upgraded biogas should match with that of natural gas employed in vehicles. To reach the required quality, such contaminants of landfill gas as carbon dioxide, water vapour, hydrogen sulphide, etc., have to be removed. After upgrading, biogas is subjected to compression. Upgraded biogas is stored at 200 to 250 bars in pressure vessels made of steel or aluminium composite materials allowing its delivery directly to a gas filling station [4].

Upgraded biogas can be used in the same way and in the same vehicles as natural gas. Currently, there are several dozen cities where diesel fuel is replaced by biomethane in public transport, taxi, as well as in the heavy vehicles of biogas production companies.

The upgraded biogas produced at landfills can be injected into a natural gas grid to be spread there after it has reached the quality standards of natural gas and is compressed up to the pressure required for pipelines (so that at the biogas-natural gas connecting point it is higher than in the pipeline). Particular limiting requirements stem from such parameters of biogas as its economically feasible amount, pressure (4-7 bars) at injection into grids, and the distance from a biogas upgrading station to the natural gas pipeline $(<2 \mathrm{~km})$. Very often in the closest gas grid there is a lower pressure [1].

Although specific requirements for biogas have already been worked out (see Table 2) to make it suitable for injection into a natural gas grid [2], no 
international standards exist for this purpose; currently, the national standards are in use in some developed countries, e.g. in Switzerland, Austria, Germany and France.

The standards defining the content of such components as sulphur, oxygen, particles and the water dew-point are aimed at avoiding contamination of gas grids or end-use appliances. In most cases, it is easy to comply with the standards by implementation of upgrading technologies. In some cases landfill gas is difficult to improve to the required quality owing to its high nitrogen content [4].

Table 2

Requirements for biogas for injection into a natural gas grid [2]

\begin{tabular}{|l|c|c|}
\hline \multicolumn{1}{|c|}{ Parameter } & Unit & Required \\
\hline Carbon dioxide $\left(\mathrm{CO}_{2}\right)$ & vol-\% & $<8$ \\
\hline Water dew-point & ${ }^{\circ} \mathrm{C}$ & -10 \\
\hline Oxygen $\left(\mathrm{O}_{2}\right)$ & vol-\% & 0.5 \\
\hline Hydrogen sulphide $\left(\mathrm{H}_{2} \mathrm{~S}\right)$ & $\mathrm{mg} / \mathrm{nm}^{3}$ & 5 \\
\hline
\end{tabular}

In compliance with the EU regulations, a guideline for gas grid opening to biogas and gas from biomass has been elaborated, which states that all biogas suppliers should have the guaranteed access to a gas grid.

One of the advantages of biogas injection into the natural gas grid is that such a grid connects the place of biogas production (usually in rural areas) with densely populated areas, which allows new consumers to use gas. In this way it is possible to increase the biogas production in remote areas, not being worried about utilisation of the biogas produced.

The main barriers to injection of upgraded biogas are the high costs of upgrading and grid connection. Injection into a grid is limited by location of biogas production and upgrading sites, which should be close to this grid [4].

Currently, in many cities of Europe biogas is used as transport fuel, with Sweden and Switzerland being one step ahead of other countries, since the policy of these states supports biogas projects [1].

\section{METHODS FOR UPGRADING BIOGAS}

Biogas produced in landfills consists mainly of methane and carbon dioxide. In smaller amounts, there are present hydrogen sulphide and ammonia, and - in very small amounts - hydrogen, nitrogen, oxygen, halogenic hydrocarbons as well as water vapour, dust and organic silicon compounds.

As unprocessed biogas is almost impossible to use because of contaminants, for making it suitable for grid injection or as transport fuel it is necessary to process the biogas (usually two processes are needed).

During a purification process the contaminants that are present in small amounts in biogas are separated, since some of them can adversely affect the biogas distribution systems or equipment: disturbances can be caused, e.g., by corrosion, sediments, or mechanical equipment wear. Contaminants can also cause emissions of undesirable exhaust gases such as sulphur oxide compounds, dioxins 
or furans. Substances to be separated from biogas to reduce the operating costs are water, hard particles, organic silicon compounds, and halogenic hydrocarbons.

During the process of biogas upgrading a separation of methane and carbon dioxide usually occurs. In this stage, the heat of biogas combustion increases, which is determined by Wobbe's index and other parameters allowing upgraded biogas to reach the quality comparable with that of natural gas in a grid or the standards for transport fuel.

Figure 1 schematically shows the stages of upgrading the biogas obtained at landfills or bioreactors to make possible its injection into a natural gas grid or the use as transport fuel.

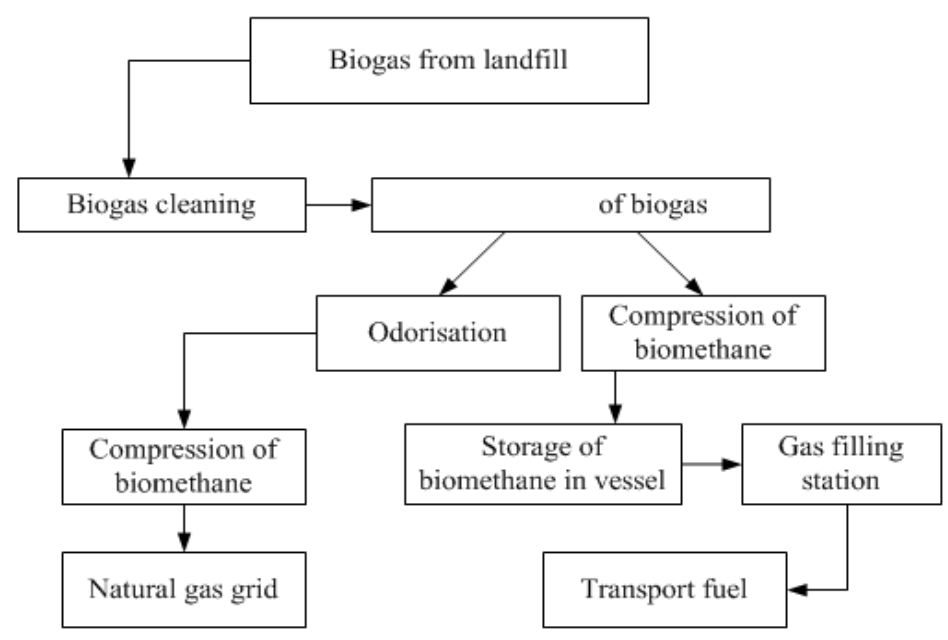

Fig. 1. Stages of upgrading the biogas quality.

To be used in natural gas grids, biogas should meet several conditions, for example: specific odours used in natural gas system have to be added (in the process of odorisation); the pressure should be increased to match with the pressure in the respective section of natural gas grid; and so on.

For using in transport, biogas storage and filling systems should be developed to provide effective supply to vehicles.

The purification process usually consists of separation from biogas of hydrogen sulphide, halogenic hydrocarbons, ammonia and organic silicon compounds (present in small quantities) as well as of water vapour thus reducing the moisture content of biogas. Such a process involves absorbers, separators, condensing equipment, and filters. Water separation from biogas can be done with different methods: cooling, adsorption, and absorption.

The upgrading of biogas is actually its purification, when the ballast substances are removed thus increasing its methane content. The concentration of methane (usually 50-65\%) in biogas is increased over 95\%. To reach the required Wobbe index of gas, carbon dioxide has to be removed.

Methods for reducing carbon dioxide (in which the hazardous contaminants are separated) are as follows.

- Carbon dioxide absorption using both water and chemical compounds. 
- Adsorption by pressure change, with pressure varying in the layers of adsorber using molecular sieves.

- Cryogenic separation, using low temperatures (close to $-90{ }^{\circ} \mathrm{C}$ ) and high pressure (40 bars on the average) to facilitate condensation of carbon dioxide.

- Technology based on the membrane principle, using material with selective permeability for exhaling through a thin its layer (membrane) some specific molecules of unprocessed biogas, e.g. molecules of carbon dioxide, hydrogen sulphide and those blocking methane.

- Chemical conversion, where carbon dioxide and hydrogen are converted into methane and water.

While the first four stages are commercial, being used in the stage of biogas purification and upgrading, the chemical conversion method is still in the stage of development; currently, only the first pilot-scale equipment is available.

\section{BENCHMARKING METHOD}

The benchmarking method for estimation of biogas upgrading schemes has been developed to compare the indicators of different biogas purification and upgrading solutions taking into account the threshold values.

The benchmarking model of biogas purification and upgrading includes an input data module, technological, economic and climate-related calculation modules, and a module accounting for threshold values (see Fig. 2).

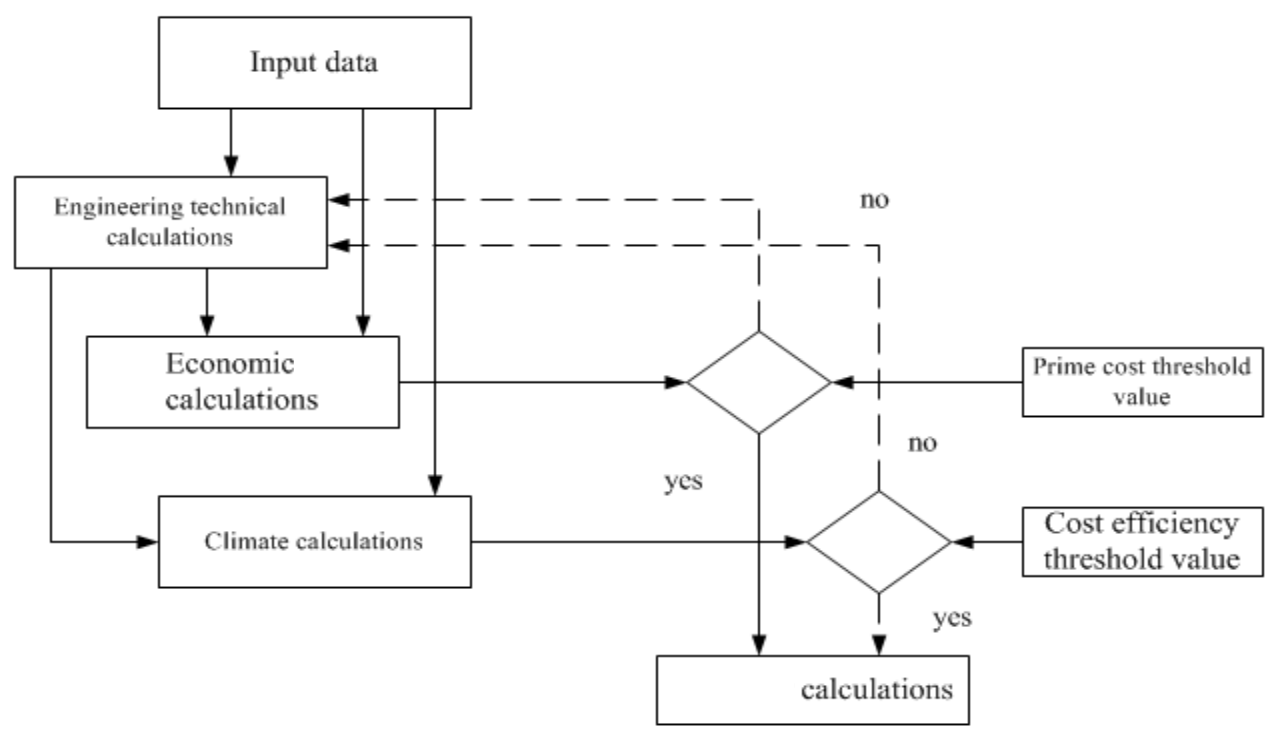

Fig. 2. Benchmarking model algorithm of biogas purification and upgrading.

In this case the indicators are chosen which cover both economic and ecologic comparison of technological solutions. In the world practice, hundreds of the eco-indicators are known from which the most suitable should be chosen to describe in the most precise way the production of biogas to be used in natural gas grids and vehicles. In this work, the chosen eco-indicators are the prime cost of 
biogas purification and storage, and the cost efficiency of the reduction in greenhouse gas emissions (GGEs).

The prime cost of biogas purification and storage is determined using the data on the capital investments in equipment, the operational expenses, the biogas quantities, the efficiency of technological equipment and systems, and the greenhouse gas emissions.

The prime cost of technological solutions of biogas purification and storage is determined for:

1) the quantity of upgraded biogas

$$
T_{b g}=\frac{(K+A)}{B},
$$

where $T_{b g}-$ costs of biogas upgrading process, $\mathrm{LVL} / \mathrm{m}^{3}$,

$K$ - capital investment, LVL,

$A$ - operational expenses in the whole time of technologic operation, LVL,

$B$ - quantity of biogas in the whole time of technologic operation, $\mathrm{m}^{3}$;

2) the quantity of upgraded biogas per energy unit

$$
T_{e}=\frac{(K+A) \times 100}{c_{\mathrm{CH}_{4}} \times B \times W_{L}},
$$

where $T_{e}$ - prime cost of biogas energy, LVL/MWh,

$c_{\mathrm{CH}_{4}}$ - methane concentration in biogas, $\%$,

$W_{L}-$ Wobbe index, $\mathrm{MWh} / \mathrm{m}^{3}$.

The cost efficiency of biogas purification and upgrading for GGE reduction owing to implementation of technological solutions can be determined by the equation:

$$
M=\frac{K}{c_{\mathrm{CH}_{4}} \times \rho_{\mathrm{CH}_{4}} \times B \times R_{\mathrm{CH}_{4}}},
$$

where $M-$ cost efficiency, $\mathrm{LVL} / \mathrm{tCO}_{2}$,

$\rho_{\mathrm{CH}_{4}}$ - methane density, $\mathrm{kg} / \mathrm{m}^{3}$,

$R_{\mathrm{CH}_{4}}$ - emission factor of methane greenhouse gases, $\mathrm{tCO}_{2 \text { ekv }} / \mathrm{tCH}_{4}$.

The threshold values of the three chosen eco-indicators are dictated by the development of GGE market as well as by proper legislation concerning the renewable energy sources and the tariffs on natural gas in Latvia.

One of the main parameters for the input data module is the biogas output from a landfill. To determine the potential of landfill gas production, scientists from several countries have worked out alternative models, which differ not only in the modelling principles but also in the division into time periods (months, years etc.).

The quantity of gas produced in a landfill can be determined by a differential equation with definite assumptions - that the biogas production in landfill proceeds 
in two phases. The first phase is intensification of the production, whereas the second one is an opposite process, with the same amount of gas produced in both phases. This can be described with the equation system:

for the first phase, $0<\tau<\tau_{1 / 2}$

$$
d B_{I} / d \tau=k_{1} \times B_{I},
$$

and for the second phase, $\tau>\tau_{1 / 2}$

$$
d B_{I I} / d \tau=-k_{2} \times B_{I I},
$$

where $B_{I}$ - the quantity of gas produced in the first phase before time $\tau$;

$B_{I I}$ - the quantity of gas left in the second phase that could be produced after time $\tau$;

$k_{1}$ - the intensity factor of gas production in the first phase;

$k_{2}$ - the intensity factor of gas production in the second phase;

$\tau$ - time.

Two last equations are used in the models for determination of the landfill biogas production potential. One of the most popular models employed for tasks of the kind is LandGEM.

\section{TESTING OF THE BENCHMARKING METHOD FOR BIOGAS UPGRADING AT THE „DAIBE” LANDFILL}

The potential of biogas production from the waste disposed in a solid municipal landfill calculated with the help of LandGEM model is illustrated by Fig. 3.

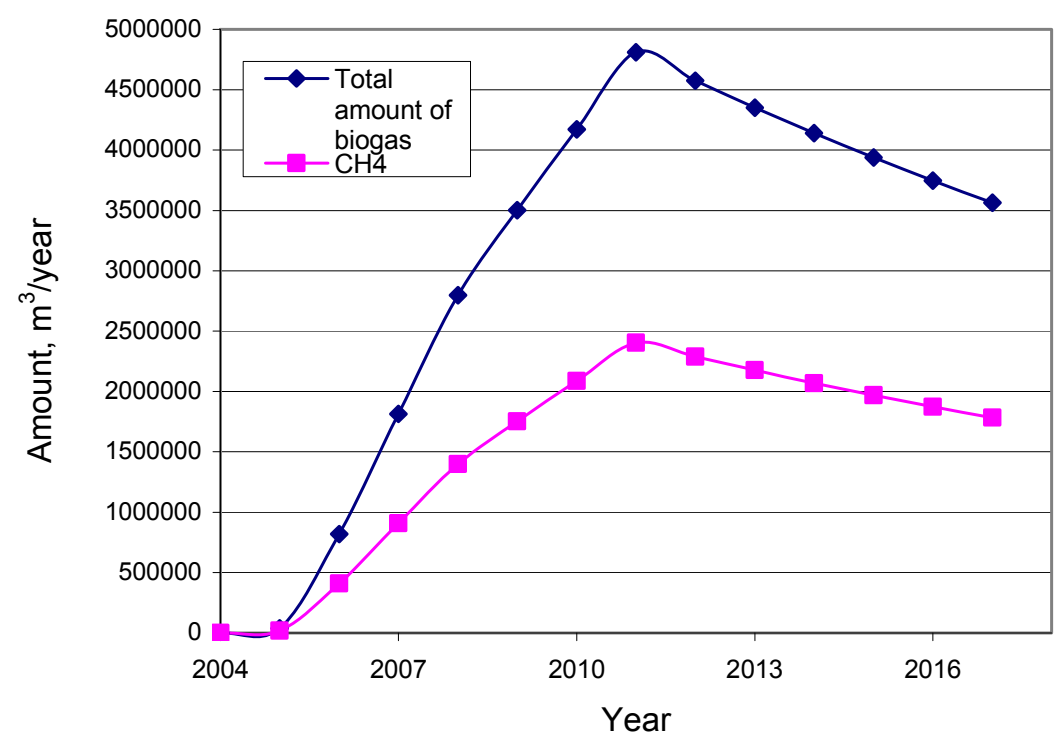

Fig. 3. The amount of biogas produced at landfill "Daibe". 
In total, the biogas production is determined adding the quantity of annually produced methane recalculated for every chosen biogas upgrading technology. The total calculated quantity of biogas at the landfill is $42266 \mathrm{~m}^{3}$. The landfill will be operated 12 years.

To determine what technology has to be chosen for the „Daibe” landfill it is necessary to compare different biogas upgrading technologies. Technicallyeconomic and climate evaluation is done for the four technological methods:

- absorption;

- adsorption;

- cryogenic separation;

- membrane technology.

It is important that in the estimation of technological methods for determination of produced upgraded biogas B (see Eqs. (4), (5)) the incoming flow of unprocessed biogas and the methane content in biogas $\mathrm{c}_{\mathrm{CH} 4}$ (in percent) are taken in equal amounts. The percentage of methane in biogas is determined by processing the data obtained at landfill "Daibe" (see Fig. 4).

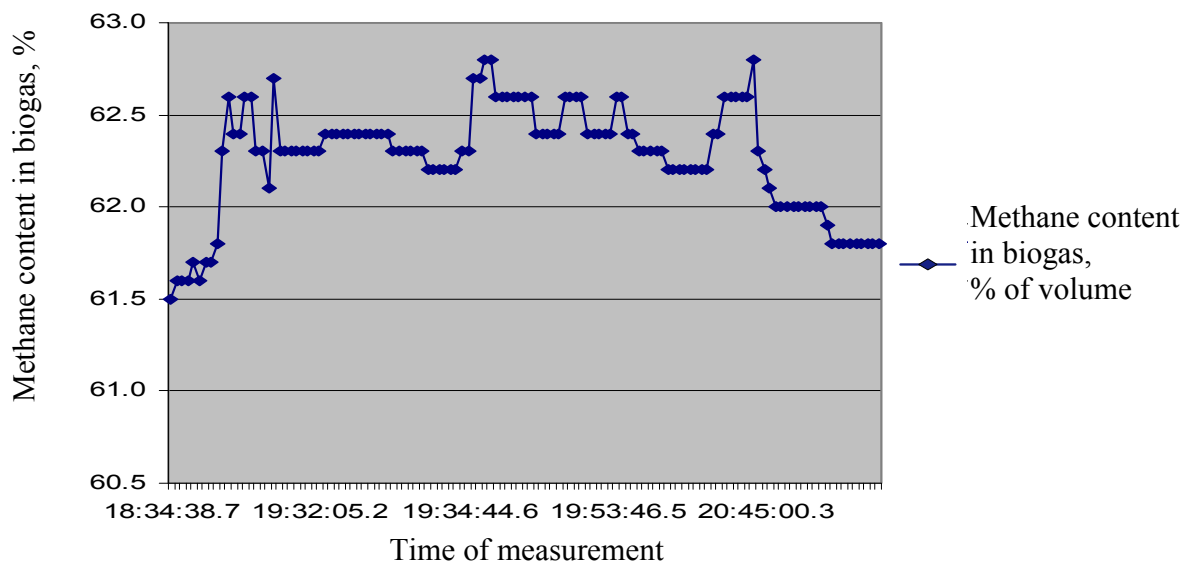

Fig. 4. Methane concentration in the biogas produced at "Daibe" landfill.

In the estimation of each technological method the total calculated amount of biogas of $42300 \mathrm{~m}^{3}$ (3500 m/year) is taken as the incoming flow of unprocessed biogas, with the percentage of methane in biogas being $60 \%$.

To make the comparison adequate, the input data on biogas were made identical for each technological method when calculating the costs of biogas purification and upgrading per $1 \mathrm{~nm}^{3}$ for the whole period of 12 years of landfill biogas utilisation.

Another group of the input data refers to the implementation of technicallyeconomic estimation of solutions for absorption without regeneration, adsorption at different pressures, cryogenic separation, and membrane technologies. Analysis and mathematical processing of the data on capital investments and equipment operation \& maintenance costs are performed based on the information from numerous literature sources. Into the investments the costs of equipment (com- 
pressors, columns, heat exchangers, etc.) are included to calculate those needed for each technological method and system development. In the total investments for biogas upgrading technology the highest is for the cryogenic separation $1057219 \mathrm{LVL}$, whereas the smallest is for the membrane technology - only $271141 \mathrm{LVL}$.

The prime cost of upgraded biogas for four methods is shown in Fig. 5. The benchmarking is in this case the purchasing tariff on natural gas (the full curve refers to the current tariff, and the dashed one - to the biogas tariff at a fuel filling station). As follows from the results of economic analysis, the use of cryogenic upgrading method at landfill "Daibe" can cause economical losses, therefore this method should be declined; the other methods are more profitable.

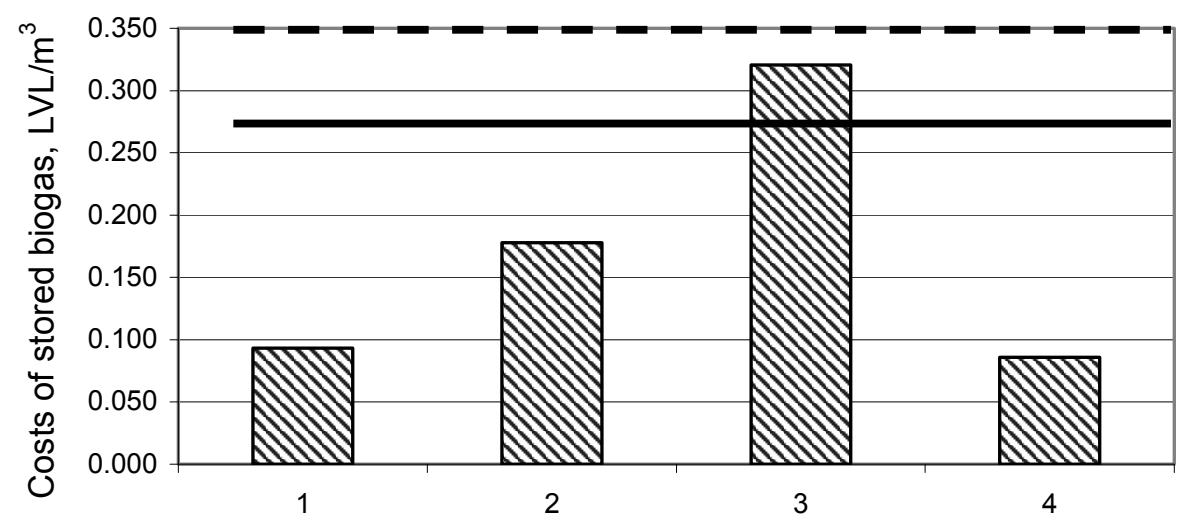

Fig. 5. Prime cost of biogas upgrading for the methods: 1 - absorption; 2 - adsorption; 3 - cryogenic separation; 4 - membrane technology.

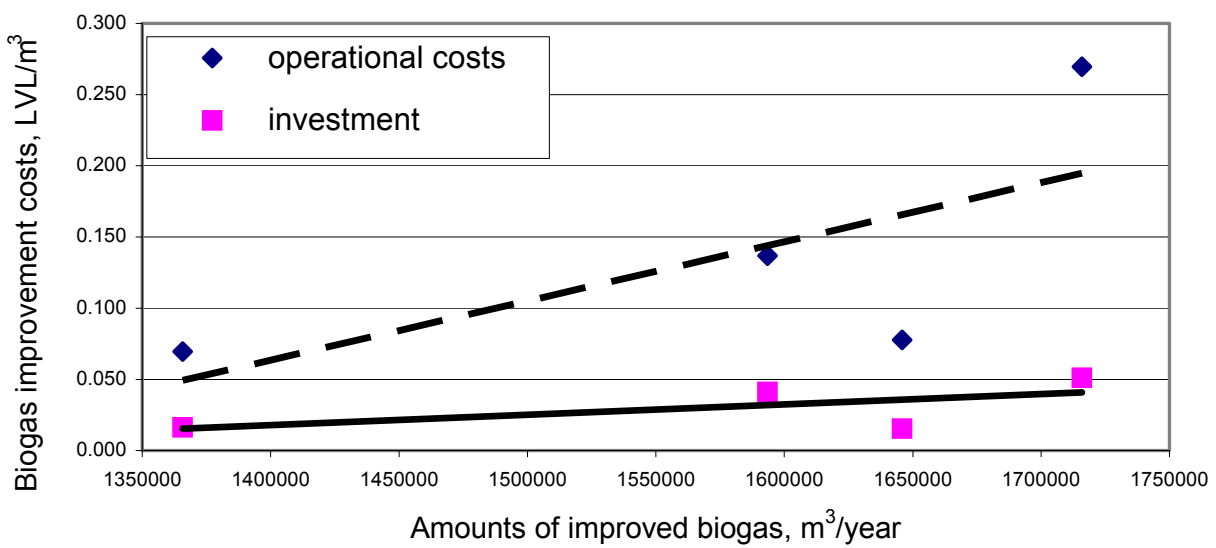

Fig. 6. Cost division and analysis.

Based on the extended cost analysis of technological solutions it can be stated that, depending on the amounts of upgraded biogas, the investments play a less important role than the operational costs, since higher investments allow greater amounts of upgraded biogas to be obtained (see Fig. 6). As shown in this 
figure, the initial capital investments do not exceed $0.05 \mathrm{LVL} / \mathrm{m}^{3}$. However, the difference in the equipment operational costs is greater. To realise the cryogenic method is especially expensive because of the necessity to maintain high temperatures and pressures.

Further data analysis gives a similar result. The prime cost of upgraded biogas per energy unit for four methods shows that if the variable tariff on natural gas exceeds $30 \mathrm{LVL} / \mathrm{MWh}$ for minor consumers (see dashed benchmarking in Fig. 7), the expensive cryogenic biogas upgrading could become competitive as well. The dashed line characterises the benchmarking for the average consumer at present. For the landfill „Daibe” the greater economy can be achieved by using the absorption method. As can be seen, the prime cost of upgraded biogas could become competitive also at the use of wood chips - seemingly a more comfortable fuel for many consumers of energy resources.

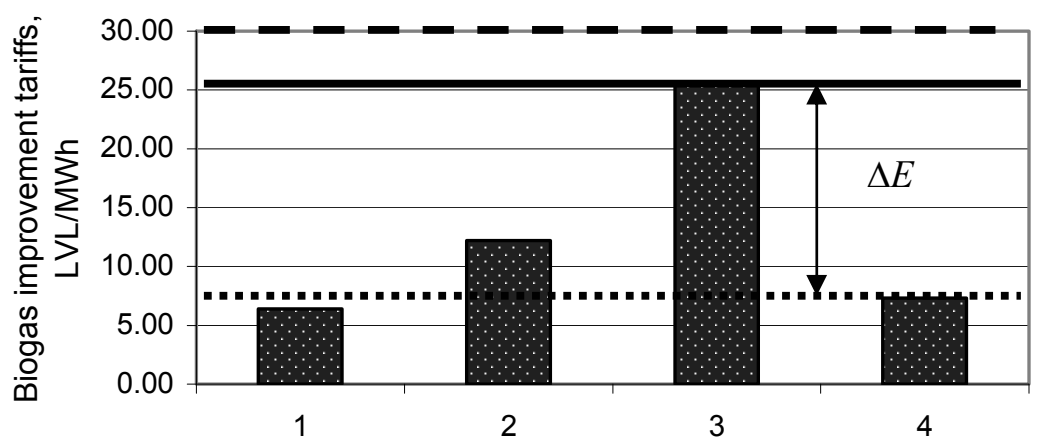

Fig. 7. Specific costs of upgraded biogas energy for the methods:

1 - absorption; 2 - adsorption; 3 - cryogenic separation; 4 - membrane technology.

The economy achieved from biogas upgrading can be calculated graphically, by determination of the difference between the benchmarking and the specific technology realisation costs:

$$
\Delta E=\left(T_{e l \overline{\mathrm{m}}}-T_{e}\right) \times Q,
$$

where $\Delta E$ - economy, LVL,

$Q$ - biogas energy, MWh,

$T_{\text {elim }}$ - benchmarking of the purchase tariff on biogas energy, LVL/MWh.

The costs connected with GGE reduction are determined in a manner similar to that for economy calculation, i.e.

$$
\Delta M=\left(M_{l \overline{\mathrm{m}}}-M\right) \times C_{\mathrm{CO}_{2}},
$$

where $\Delta M$ - economy, LVL,

$\mathrm{C}_{\mathrm{CO}_{2}}$ - quantity of greenhouse gases in biogas, $\mathrm{tCO}_{2}$,

$M_{l i m}$ - threshold value of cost efficiency (benchmarking), $\mathrm{LVL} / \mathrm{tCO}_{2}$.

The results of the analysis show that it is possible to obtain economy from 3.6 million to 5.7 million LVL within the operation time of biogas upgrading station (12 years). Also, additional income of $1-4$ million LVL is possible from the emission trading market in the same time period. 


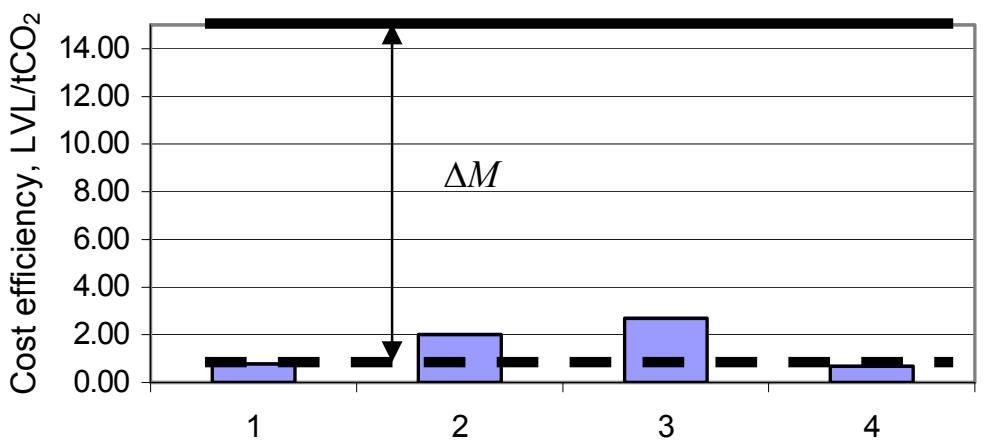

Fig. 8. Cost efficiency of biogas upgrading technologies.

\section{CONCLUSIONS}

1. Experience of such countries as Germany, Switzerland, Sweden and France shows that biogas from landfills and bioreactors could be used not only to produce heat and electricity by cogeneration plants but also as a transport fuel; alternatively, it can be injected into a natural gas grid. Several biogas projects have been applied in practice for already more than 20 years.

2. To make possible using biogas as a transport fuel or its injection into a natural gas grid it should be processed. The first stage of biogas processing is purification of biogas. In this stage biogas is cleaned from such contaminants present in biogas in small amounts as hydrogen sulphide $\left(\mathrm{H}_{2} \mathrm{~S}\right)$, organic silicon compounds, halogenic hydrocarbons, oxygen $\left(\mathrm{O}_{2}\right)$, nitrogen $\left(\mathrm{N}_{2}\right)$ and water, because they can cause damage to natural gas grids and vehicle engines. At the following stage of biogas upgrading mainly separation of carbon dioxide $\left(\mathrm{CO}_{2}\right)$ from methane $\left(\mathrm{CH}_{4}\right)$ is done; during this stage the biogas combustion heat and Wobbe index are increased, which makes the upgraded biogas corresponding to the quality requirements established for natural gas.

3. In the European Union, in compliance with Directive 2003/30/EC on the promotion of the use of biofuels or other renewable fuels for transport, all EU countries are obliged to develop and implement policies facilitating the use of biofuels in the transport sector. The goals set in 2003 determined that by the end of $20052 \%$ of the transport sector energy had to be replaced with biofuel, whereas in 2010 this share should be already $5.75 \%$. Nowadays, in the member countries of European Union for the use of biogas as a transport fuel the standard SS 145418 ,Motor fuels - Biogas as fuel for high-speed Otto engines" (Sweden) is officially accepted. As of yet, no international standards exist for the injection of biogas into natural gas grids; however, more developed countries have elaborated their own standards in this field.

4. The most popular methods of biogas upgrading in the world are gas scrubber, adsorption at pressure change, cryogenic separation, and membrane separation.

5. To calculate the prime costs of upgraded biogas per $1 \mathrm{Nm}^{3}$ in the different biogas upgrading technologies it is necessary to know the amount of biogas produced at a landfill; in this paper it is done with the help of LandGEM 3.02 model, finding in advance the parameters and specific values characterising in 
the best way the solid municipal waste landfill: the year of opening and closing the first depository of the landfill, methane origination coefficient, potential methane production capacity, the methane content of biogas, and the waste amount received for deposition from 2004 to 2008. The modelling results show that, while in 2005 the total biogas amount produced by the solid municipal waste landfill „Daibe” was only $37020 \mathrm{~m}^{3} /$ year, in 2006 it was 818100 $\mathrm{m}^{3} /$ year, and in 2007 - already $1815000 \mathrm{~m}^{3} /$ year. The maximum produced amount of biogas from the first depository could to be reached in 2011$4810000 \mathrm{~m}^{3} /$ year, after which a gradual decrease in the biogas production is expected. The calculations are based on the use of $3502000 \mathrm{~m}^{3}$ of biogas in $2009\left(\sim 414 \mathrm{~m}^{3}\right.$ of biogas $\left./ \mathrm{h}\right)$, assuming that the equipment will be operated $8460 \mathrm{~h} /$ year.

6. According to the economic estimation of four biogas upgrading technologies, the smallest costs for upgrading $1 \mathrm{~m}^{3}$ of biogas are for the membrane technology $-0.10 \mathrm{Ls}$; for the gas scrubber these are $0.11 \mathrm{Ls}$, and for pressure change adsorption -0.22 Ls. The most expansive technology of biogas purification and upgrading is the cryogenic separation -0.37 Ls per $1 \mathrm{~m}^{3}$. Although the mentioned membrane technology is cost-effective, however comparatively low maximum achievable productivity of equipment $(78 \%)$ and maximum achievable purity of methane $(89.5 \%)$ are not sufficient for the use of biogas improved with this technology in vehicles as fuel or for its injection into a natural gas grid. Gas scrubber is approved as the most beneficial and suitable technology for biogas upgrading (considering the costs, the maximum achievable equipment productivity and the methane purity) for the solid municipal waste landfill „Daibe”.

\section{REFERENCES}

1. Plombin, Ch., \& Hugosson, B. (2003). TrendSetter report No 2003:3, Biogas as Vehicle Fuel: A European Overview. Stockholm.

2. Persson, M., Jönsson, O, \& Wellinger, A. (2006). Biogas upgrading to vehicle fuel standards and grid injection, Task 37: Energy from biogas and landfill gas. IEA Bioenergy.

3. Biogas as a road transport fuel: an assessment of the potential role of biogas as a renewable transport fuel. (2006). National Society for Clean Air and Environmental Protection.

4. Blumberga, D., Dzene, I., Al Sedi, T., Rucs, D., Prasls, H., Ketners, M., Finstervalders, T., Folka, S., \& Jansens, R. (2008). Biogāzes rokasgrāmata. Rīga: Ekodoma.

\section{LĪMEN̦ATZĪMES METODE BIOGĀZES UZLABOŠANAS METOŽU VĒRTĒŠANAI}

D. Blumberga, Ģ. Kuplais, I. Veidenbergs, E. Dāce

Kopsavilkums

Biogāzi vairāk vai mazāk iespējams lietot visās iekārtās, kas izstrādātas dabasgāzes lietošanai, taču neattīīitu biogāzi izmantot praktiski ir neiespējami tās sastāvā esošo piemaisījumu dēḷ. Lai biogāzi varētu veiksmīgi padot dabasgāzes tīklā vai izmantot kā degvielu transportlīdzekḷos, ir jāveic tās apstrāde, kas pamatā sastāv no diviem posmiem: 
- biogāzes attīriššanas procesa, kad tiek atdalīti biogāzē nelielā daudzumā esošie piemaisījumi;

- biogāzes uzlabošanas procesa, kad no metāna tiek atdalīts oglekḷa dioksīds.

Pastāv vairākas metodes biogāzes uzlabošanai, no kurām pasaulē populārākās ir gāzes skalotne, spiediena maiṇas absorbcija, kriogēnā atdalī̌sana un biogāzes uzlabošana, izmantojot membrānatdalīšanu. Lai dažāau alternatīvo risinājumu indikatorus varētu salīdzināt savā starpā un ar to robežvērtībām, darbā ir izveidota līmeņatzīmes metode biogāzes uzlabošanas shēmu vērtēšanai. Biogāzes attīrīšanas un uzlabošanas līmeņatzīmes modelis ietver ievaddatu moduli, inženiertehnisko, ekonomisko un klimata aprēksinu, kā arī robežvērtību moduļus. Metodei izvēlētie indikatori vienlaikus aptver inženiertehnisko risinājumu ekonomisko un ekolog̣isko salīdzinājumu, un tie ir biogāzes attīrī̌sanas un uzglabāšanas pašizmaksa un siltumnīcefekta gāzu emisiju samazināšanas izmaksu efektivitāte.

Veicot izveidotās līmeņatzīmes metodes aprobāciju biogāzes uzlabošanai cieto sadzīves atkritumu poligonā „Daibe”, secināts, ka tajā par visizdevīgāko un vispiemērotāko biogāzes uzlabošanas tehnologiju gan izmaksu, gan maksimāli sasniedzamās iekārtas ražības, gan maksimāli sasniedzamās metāna tīrības ziṇā atzīstama gāzes skalotne.

25.07.2009. 